\title{
In vitro adventitious shoot regeneration from leaf explants of some apricot cultivars
}

\section{Regeneração in vitro de brotações adventícias em explantes foliares de alguns cultivares de damasco}

\section{Olga Vladimirovna Mitrofanova' ${ }^{1}$, Irina Vjacheslavovna Mitrofanova ${ }^{1 *}\left(\mathbb{C}\right.$, Tatyana Nikolaevna Kuzmina ${ }^{1}$,

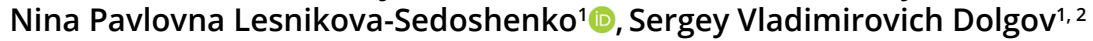

\author{
${ }^{1}$ Federal State Funded Institution of Science “The Labor Red Banner Order Nikita Botanical Gardens - National Scientific Center, Russian Academy \\ of Sciences", Yalta, Russia \\ ${ }^{2}$ Branch of Shemyakin and Ovchinnikov, Institute of Bioorganic Chemistry, Russian Academy of Sciences, Moscow, Russia \\ ${ }^{*}$ Corresponding author: irimitrofanova@yandex.ru \\ Received in January 22, 2019 and approved in April 16, 2019
}

\begin{abstract}
Apricot is one of the most valuable commercial fruits. In vitro propagation of apricot is very important for rapid multiplication of cultivars with desirable traits and production of cleaning up and virus-free plants. Low frequency of multiplication is the main limiting factor for traditional propagation methods. In this regard, the objective of our investigation was to study the morphogenetic capacity of apricot leaf explants of the promising cultivars 'Iskorka Tavridy', 'Magister' and 'Bergeron' for regeneration system development and solving some breeding questions. The source of explants was in vitro plants regenerated and cultured on QL medium. Leaves were maintained in the dark at $24 \pm 1{ }^{\circ} \mathrm{C}$ in thermostat for three-four weeks. Morphogenic callus and structures were mainly formed at the central and proximal parts of leaves on MS, QL and WPM media with 1.5 or $2.0 \mathrm{mg} \mathrm{L}^{-1} \mathrm{BAP}$ and 1.5 or $2.0 \mathrm{mg} \mathrm{L}^{-1} \mathrm{IAA}$ in different combinations, or TDZ $\left(0.6\right.$ and $\left.1.3 \mathrm{mg} \mathrm{L}^{-1}\right)$. Callus with adventive buds was transferred to regeneration medium and placed into a growth chamber at $24 \pm 1{ }^{\circ} \mathrm{C}$ and 16 -hour photoperiod with a light intensity of $37.5 \mu \mathrm{mol} \mathrm{m}^{-2} \mathrm{~s}^{-1}$. The best results were obtained when adaxial leaf surface was in contact with the culture medium. Frequency of leaf callus formation on MS medium with $1.5 \mathrm{mg} \mathrm{L}^{-1} \mathrm{BAP}$ and $1.5 \mathrm{mg} \mathrm{L}^{-1}$ IAA was higher in the explants of 'Iskorka Tavridy' (80.0\%) than in - 'Bergeron' (50.0\%) and 'Magister' (36.7\%). The best results of callogenesis for 'Magister' was obtained on MS medium with $1.3 \mathrm{mg} \mathrm{L}^{-1} \mathrm{TDZ}$ (53.3\%). Active microshoot regeneration in 'Iskorka Tavridy' cultivar was shown on MS medium with BAP and IAA and in 'Magister' cultivar - on MS medium with TDZ. Rhizogenesis was obtained on half strength MS medium with $2.0 \mathrm{mg} \mathrm{L}^{-1}$ IBA.
\end{abstract}

Index terms: Prunus armeniaca L.; genotype; leaf culture; gemmiferous callus; microshoot.

\begin{abstract}
RESUMO
O damasco é considerado uma das frutas mais valiosas comercialmente. A propagação in vitro de damasco é muito importante para a multiplicação de cultivares com características desejáveis, saudáveis e livres de vírus. O fator limitante para a propagação por métodos convencionais é a baixa frequência na multiplicação. Nesse contexto, o objetivo desse estudo foi investigar a capacidade morfogenética de explantes foliares das cultivares 'Iskorka Tavridy', 'Magister' e 'Bergeron' visando o desenvolvimento de sistema de regeneração e solucionar algumas questões relacionadas ao melhoramento genético. Plantas regeneradas in vitro e cultivadas em meio QL foram usadas como fonte de explantes. Folhas foram mantidas no escuro a $24 \pm 1$ o C durante 3 a 4 semanas. Estruturas calogênicas e calos morfogenético foram observados principalmente na parte central e proximal das folhas mantidas em meios MS, QL e WPM contendo 1,5 ou 2,0 mg L-1 de AIA em diferentes combinações além do TDZ (0,6 e $1.3 \mathrm{mg} \mathrm{L}^{-1}$ ). Calos apresentando gemas adventícias foram transferidas para meio de regeneração e mantidos em sala de crescimento a $24 \pm 1^{\circ} \mathrm{C}$ com fotoperíodo de 16 horas e intensidade luminosa de $37,5 \mu \mathrm{mol} \mathrm{m}^{-1} \mathrm{~s}^{-1}$. Os melhores resultados foram observados quando o lado adaxial das folhas ficaram em contato com o meio de cultura. A frequência na formação de calos é maior quando os explantes foliares são inoculados em MS contendo 1,5 mg $\mathrm{L}^{-1}$ de BAP ou AIA para os cultivares 'Iskorka Tavridy' (80\%), 'Bergeron' (50\%) e (36,5\%). A maior formação de calos (53,3\%) no cultivar 'Magister' foi observada com o uso de MS contendo 1,3 mg L-1 TDZ. A regeneração de microbrotações dos cultivares 'Iskorka Tavridy' e 'Magister' foi observada em meio MS contendo BAP or AIA and TDZ, respectively. A formação de raízes foi obtida em meio MS meia força contendo $2,0 \mathrm{mg} \mathrm{L}^{-1} \mathrm{AlB}$.
\end{abstract}

Termos para indexação: Prunus armeniaca L.; genótipo; cultivo de folhas; calos; microbrotações. 


\section{INTRODUCTION}

Apricot (Prunus armeniaca L., genus Prunus L., family Rosaceae Juss.) is the second major industrial stone fruit crop in the world. It is widespread in European countries, Iran, Turkey, USA and others (Gorina; Richter, 2018; Potter, 2012). In the Russian Federation, the main regions for apricot growing are Crimea, the Caucasus, southern part of Central Black Earth Economic Region and the Urals (Korzin; Gorina; Mesyats, 2018; Kramarenko, 2018; Nozdracheva, 2008). Apricot fruits are characterized with high taste qualities, rich in mineral and biologically active substances. They are consumed fresh and used in the production of dried fruits, canned goods, jams and juices. Apricot plants are characterized with rapid growth and early start of fruiting period. At present, there is a decrease of the areas under the apricot orchards, which is primarily due to the irregular fruiting of apricot genotypes and their damages by Sharka disease (Plum pox virus, PPV) that results in the crop losses and death of trees (Cambra et al., 2006; Mitrofanova et al., 2015, 2017; Nemeth, 1994). The use of traditional breeding methods for creation of the cultivars resistant to PPV is ineffective because of the lack of resistance donors (Bourguiba et al., 2018; Zhebentyayeva et al., 2012). Modern methods of biotechnology and genetic engineering make it possible to accelerate significantly the creation of PPV-resistant high-yield cultivars of stone fruit crops, including apricot (Gentile; Monticelli; Damiano, 2002; Ilardi; Tavazza, 2015; Mitrofanova et al., 2015, 2017; Mitrofanova et al,. 2016; Mourenets; Dolgov, 2016; Rubio et al., 2018). The establishment of an effective genetic transformation system depends on the availability and reliability of the developed regeneration systems via somatic tissues culture. Unfortunately, the existing apricot regeneration systems are not always reproducible, since the optimal regeneration conditions are affected by the number of factors, and primarily by the genotype (Escalettes; Dosba, 1993; Perez-Tornero; Burgos; Egea, 1999; Perez-Tornero et al., 2000; Ruiz et al., 2011). The main trend of the presented study was to investigate the factors stimulated induction of adventitious bud and microshoot regeneration from leaf explants of the new promising apricot cultivars 'Iskorka Tavridy' and 'Magister' originated in Nikita Botanical Gardens (Russia) and cultivar 'Bergeron' (France) widespread growing in the European countries.

The object of this work was to study the main ways of morphogenetic capacity induction in leaf explants of apricot cultivars 'Iskorka Tavridy', 'Magister' and 'Bergeron' in order to develop an effective plant regeneration system.

\section{MATERIAL AND METHODS}

\section{Plant material}

The studies were carried out in 2016-2018 in the Plant Developmental Biology, Biotechnology and Biosafety Department in the FSFIS "Nikita Botanical Gardens - National Scientific Center of the Russian Academy of Sciences" (FSFIS "NBG-NSC").

The plant materials of the investigation were three apricot cultivars from the collection plots of FSFIS "NBG-NSC": 'Iskorka Tavridy' and 'Magister' are of local breeding (FSFIS "NBG-NSC", Russia) and 'Bergeron'foreign breeding (France).

The cultivars 'Iskorka Tavridy' and 'Magister' are new and promising for commercial culture in the South of Russia. Higher resistance to spring freezing of generative buds, bright colour of fruits and stable yield are characteristics of these cultivars. They are included in the State Register of Protected Breeding Achievements in the Russian Federation. The cultivar 'Bergeron' is characterized by drought-resistance, large size of fruits and their orange colour. It could be the source of those features in apricot breeding.

\section{Experiments with explants in vitro}

Apricot leaves 3-5 $\mathrm{mm}$ by length collected from two month plantlets of three apricot cultivars previously propagated by apical meristem culture in vitro on $\mathrm{QL}$ medium (Quoirin; Lepoivre, 1977) with $0.5-1.0 \mathrm{mg} \mathrm{L}^{-1}$ BAP (6-benzylaminopurine) and $0.15 \mathrm{mg} \mathrm{L}^{-1} \mathrm{IBA}$ (indole3-butyric acid) were used as primary explants. For in vitro plant culture experiments the methods by Kyte et al. (2013); Mitrofanova et al. (1999); Perez-Tornero and Burgos (2007); Petri; Alburquerque and Burgos (2015) were applied. In vitro morphogenesis and induction of microshoot regeneration from leaf explants were carried out on three modified media: MS (Murashige; Skoog 1962), QL and WPM (Lloyd; McCown, 1980) with vitamins and plant growth regulators (Sigma, USA). To study morphogenesis and induction of explants regeneration, BAP at the concentration 1.5 or $2.0 \mathrm{mg}$ $\mathrm{L}^{-1}$, IAA (indole-3-acetic acid) -1.5 or $2.0 \mathrm{mg} \mathrm{L}^{-1}$, TDZ (1-phenyl-3-(1,2,3-thiadiazol-5-yl) urea)-0.6 and $1.3 \mathrm{mg}$ $\mathrm{L}^{-1}$ were tested. All the applied media were supplemented with $30 \mathrm{~g} \mathrm{~L}^{-1}$ sucrose and $9 \mathrm{~g} \mathrm{~L}^{-1}$ agar (Panreac, Spain). $\mathrm{pH}$ was adjusted to 5.7 before autoclaving. The media were autoclaved at the temperature $120^{\circ} \mathrm{C}$ for $5-12 \mathrm{~min}$ in LAC 5060S sterilizer (DAIHAN LABTECH, South Korea) and sterilely poured into Petri dishes or culture vessels. 
All works were made in the aseptic conditions of the SC2 laminar flow cabinet (ESCO, Singapore).

\section{Callus induction}

Leaves $0.5-0.75 \mathrm{~cm}$ by length were collected from in vitro proliferating microshoots of the cultivars 'Iskorka Tavridy', 'Magister' and 'Bergeron'. Before the introduction, the leaves were cut across the midrib without complete separation of the segments and placed on the modified MS, QL and WPM media supplemented with $1.5 \mathrm{mg} \mathrm{L}^{-1} \mathrm{BAP}, 1.5 \mathrm{mg} \mathrm{L}^{-1} \mathrm{IAA}, 0.6$ or $1.3 \mathrm{mg} \mathrm{L}^{-1} \mathrm{TDZ}$ by their abaxial and adaxial sides. Explants were cultured in the dark during three-four weeks in a thermostat MIR-254 (SANYO, Japan) at $24 \pm 1{ }^{\circ} \mathrm{C}$. Then callus with occurred adventive buds transferred to regeneration medium and placed into a growth chamber MLR-352-PE (SANYO, Japan) at $24 \pm 1{ }^{\circ} \mathrm{C}$ and 16 -hour photoperiod under the cool white light fluorescent lamps (Philips TL, 40W) with a light intensity of $37.5 \mu \mathrm{mol} \mathrm{m} \mathrm{m}^{-2}$. Explants were subcultured every three weeks.

\section{Histological analysis of in vitro explants}

For histological analysis apricot leaf callus of the cultivars 'Iskorka Tavridy', 'Magister' and 'Bergeron' was fixed in FAA solution. After fixation, material was transferred to $70 \%$ ethyl alcohol solution. For material dehydration isopropyl alcohol was used. Further, material was kept in two xylene solutions for 2 hours in each and then embedded in paraffin. Infiltration with paraffin was carried out for 7 days. Serial sections of callus conglomerates were made by a rotary semiautomatic microtome RMD-3000 (MedTehnikaPoint, Russia). Permanent slides were stained with hematoxylin and alcian blue (Zhinkina; Voronova, 2000). The slides were analyzed using Jenaval (Carl Zeiss, Germany) and AxioScope A.1 (Zeiss, Germany) microscopes. The photomicrographs were taken with the AxioCamERc5s image analysis system (Zeiss, Germany) using the AxioVision Rel. 4.8.2 software, as well as the Canon IXUS 265HS digital camera.

\section{Root formation}

For the root formation, adventitious microshoots $2.0-2.5 \mathrm{~cm}$ by length regenerated from callus were transferred on half-strength MS medium with 1.0, 2.0, $3.0 \mathrm{mg} \mathrm{L}^{-1}$ IBA and $20 \mathrm{~g} \mathrm{~L}^{-1}$ sucrose. As a control, growth regulators free medium was used. The vessels with microshoots were placed in the growth chamber MLR325-PE (SANYO, Japan) at $24 \pm 1{ }^{\circ} \mathrm{C}, 16$-hour photoperiod with a $28 \mu \mathrm{mol} \mathrm{m}{ }^{-2} \mathrm{~s}^{-1}$ light intensity. After root formation through five-six weeks the plantlets were transferred to the pots with a mixture of peatmoss and sand (3:1).

\section{Statistical analyses}

The experiments were carried out three times in twentyfold replication for each studied genotype. The number of leaves regenerating callus was recorded after 2-3 weeks culture in the dark. The frequency of regeneration was calculated as the average percentage of calli formed morphogenic structures. The number of microshoots per explant was determined monthly during eight months of the experiment. The obtained data were processed using STATISTICA for Windows, 10.0 (StatSoft, Inc.). The means were determined according to the Duncan's Multiple Range Test, $\mathrm{P}<0.05$.

\section{RESULTS AND DISCUSSION}

The main problem of the development of adventitious bud and microshoot regeneration system from apricot leaf under in vitro conditions is the induction of morphogenic callus formation. As it is known, active division of callus cells leads to the tissue growth, its differentiation and further formation of morphogenic structures via direct and indirect regeneration (Burgos; Alburquerque, 2003; Escalettes; Dosba, 1993; Mitrofanova, 2011; Perez-Tornero et al., 2000; Petri; Scorza, 2010; Ruiz et al., 2011).

For the first time, possibilities of leaf explant morphogenetic capacity realization have been studied in the apricot cultivars 'Iskorka Tavridy' and 'Magister'.

After 8-10 days of leaf explant cultivation on the modified MS, QL and WPM media supplemented with $1.5 \mathrm{mg} \mathrm{L}^{-1}$ BAP, $1.5 \mathrm{mg} \mathrm{L}^{-1}$ IAA, 0.6 or $1.3 \mathrm{mg} \mathrm{L}^{-1} \mathrm{TDZ}$ it was noted that explants increased in sizes 1.5-2 times. Callus was formed on the leaf wound surfaces and along the vascular tissues such as edges part of the leaf, midrib and leaf petiole (Figure 1).

Active formation of the morphogenic callus occurred at the proximal part of leaves (Figure 1A). High morphogenetic capacity was noted for leaf explants adaxially in contact with the medium compared to their abaxial location (data not shown). This corresponds with the results shown by Mourenets and Dolgov (2016); PerezTornero et al. (2000); Petri and Scorza (2010), in whose works the importance of leaf explant adaxial location on culture medium surface was noted. After three-four weeks of experimental beginning, the morphogenic structures appeared in callus. 
Genotype, culture medium and plant growth regulators were the most important factors affecting callus proliferation and indirect organogenesis. More active callogenesis and morphogenic structures formation on the modified MS medium supplemented with BAP, IAA or TDZ were observed (Table 1, Figure 2).

The number of leaf explants that induced callus on MS medium with $1.5 \mathrm{mg} \mathrm{L}^{-1} \mathrm{BAP}$ and $1.5 \mathrm{mg} \mathrm{L}^{-1}$ IAA was higher in the cultivars 'Iskorka Tavridy' $(80.0 \%)$ and 'Bergeron' (50.0\%), compared to 'Magister' (36.7\%). On the same medium, the frequency of morphogenic structures regeneration from leaf explant callus was $19.5 \%, 8.6 \%$ and $4.5 \%$ in the cultivars 'Iskorka Tavridy', 'Magister' and 'Bergeron', respectively.

However, in the treatment with $1.3 \mathrm{mg} \mathrm{L}^{-1} \mathrm{TDZ}$ 'Magister' cultivar demonstrated higher regeneration frequency $(10.6 \%)$ of morphogenetic structures compared to the treatments with BAP and IAA. On QL and WPM media these rates were significantly lower (from $0.8 \%$ to $7.8 \%$ ). In the control leaf explants were necrotic and callus was not formed.

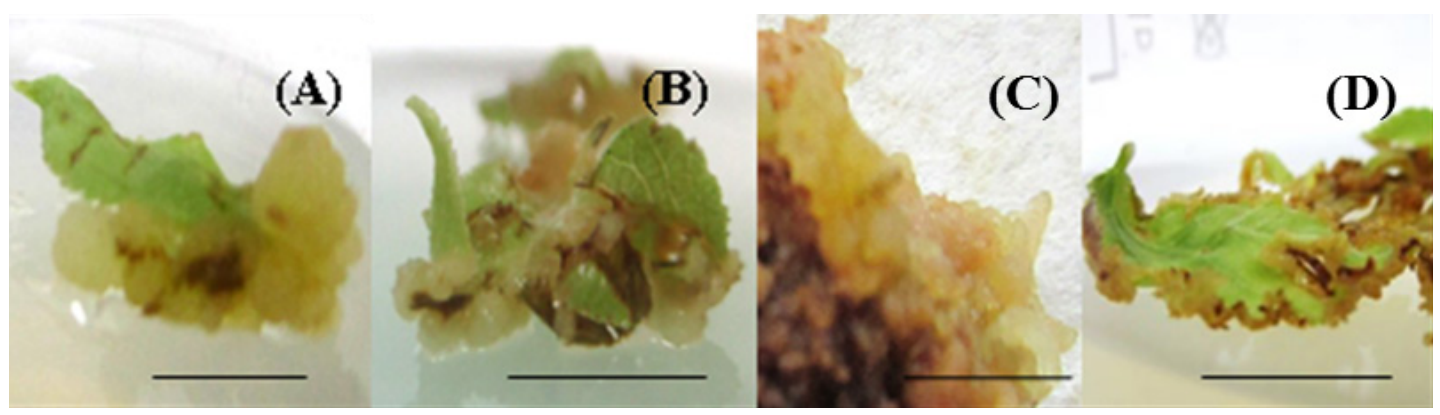

Figure 1: Formation of morphogenic callus from leaf explants of the apricot cultivars 'Iskorka Tavridy' (A, B), 'Bergeron' (D) on MS medium, supplemented with $1.5 \mathrm{mg} \mathrm{L}^{-1} \mathrm{BAP}$ and $1.5 \mathrm{mg} \mathrm{L}^{-1} \mathrm{IAA}$, and cultivar 'Magister' (C) on MS medium with $1.3 \mathrm{mg} \mathrm{L}^{-1} \mathrm{TDZ}$ after two weeks from the beginning of the experiment. $\mathrm{Bar}=1 \mathrm{~cm}$.

Table 1: Indexes of the leaf explant morphogenetic capacity in three apricot cultivars on various culture media.

\begin{tabular}{|c|c|c|c|c|c|c|}
\hline \multirow{2}{*}{$\begin{array}{l}\text { Culture medium and } \\
\text { concentration of plant } \\
\text { growth regulators }\end{array}$} & \multicolumn{3}{|c|}{ Callus produced explants (\%) } & \multicolumn{3}{|c|}{$\begin{array}{l}\text { Frequency of morphogenic structures } \\
\text { regeneration from callus (\%) }\end{array}$} \\
\hline & 'Iskorka Tavridy' & 'Magister' & 'Bergeron' & 'Iskorka Tavridy' & 'Magister' & 'Bergeron' \\
\hline \multicolumn{7}{|l|}{ MS } \\
\hline 0 (control) & $0.0 \mathrm{e}$ & $0.0 \mathrm{e}$ & $0.0 \mathrm{e}$ & $0.0 \mathrm{~d}$ & $0.0 \mathrm{~d}$ & $0.0 \mathrm{~d}$ \\
\hline $0.6 \mathrm{mg} \mathrm{L}^{-1} \mathrm{TDZ}$ & $33.3 \mathrm{~cd}$ & $33.3 \mathrm{bc}$ & $23.3 \mathrm{~cd}$ & $3.8 \mathrm{c}$ & $2.5 \mathrm{c}$ & $1.4 \mathrm{c}$ \\
\hline $1.3 \mathrm{mg} \mathrm{L}^{-1} \mathrm{TDZ}$ & $46.7 \mathrm{bc}$ & $53.3 \mathrm{a}$ & $40.0 \mathrm{bc}$ & $10.2 \mathrm{~b}$ & $10.6 \mathrm{a}$ & $2.9 \mathrm{~b}$ \\
\hline $1.5 \mathrm{mg} \mathrm{L}^{-1} \mathrm{BAP}+1.5 \mathrm{mg} \mathrm{L}^{-1} \mathrm{IAA}$ & $80.0 \mathrm{a}$ & $36.7 \mathrm{bc}$ & $50.0 \mathrm{a}$ & $19.5 \mathrm{a}$ & $8.6 \mathrm{ab}$ & $4.5 \mathrm{a}$ \\
\hline \multicolumn{7}{|l|}{ QL } \\
\hline 0 (control) & $0.0 \mathrm{c}$ & $0.0 \mathrm{~b}$ & $0.0 \mathrm{c}$ & $0.0 \mathrm{~d}$ & $0.0 \mathrm{c}$ & $0.0 \mathrm{c}$ \\
\hline $0.6 \mathrm{mg} \mathrm{L}^{-1} \mathrm{TDZ}$ & $10.0 \mathrm{~b}$ & $0.0 \mathrm{~b}$ & $0.0 \mathrm{c}$ & $2.4 \mathrm{c}$ & $0.0 \mathrm{c}$ & $0.0 \mathrm{c}$ \\
\hline $1.3 \mathrm{mg} \mathrm{L}^{-1} \mathrm{TDZ}$ & $16.7 a$ & $13.3 \mathrm{a}$ & $6.7 \mathrm{~b}$ & $5.4 \mathrm{~b}$ & $3.7 \mathrm{~b}$ & $0.5 b$ \\
\hline $1.5 \mathrm{mg} \mathrm{L}^{-1} \mathrm{BAP}+1.5 \mathrm{mg} \mathrm{L}^{-1} \mathrm{IAA}$ & $16.7 \mathrm{a}$ & $13.3 \mathrm{a}$ & $13.3 \mathrm{a}$ & $7.1 \mathrm{a}$ & $5.5 \mathrm{a}$ & $1.1 \mathrm{a}$ \\
\hline \multicolumn{7}{|l|}{ WPM } \\
\hline 0 (control) & $0.0 \mathrm{~d}$ & $0.0 \mathrm{~d}$ & $0.0 \mathrm{c}$ & $0.0 \mathrm{e}$ & $0.0 \mathrm{c}$ & $0.0 \mathrm{c}$ \\
\hline $0.6 \mathrm{mg} \mathrm{L}^{-1} \mathrm{TDZ}$ & $13.3 \mathrm{bc}$ & $10.0 \mathrm{bc}$ & $0.0 \mathrm{c}$ & $1.7 \mathrm{~cd}$ & $1.8 \mathrm{~b}$ & $0.0 \mathrm{c}$ \\
\hline $1.3 \mathrm{mg} \mathrm{L}^{-1} \mathrm{TDZ}$ & $20.0 \mathrm{ab}$ & $16.7 \mathrm{~b}$ & $6.7 \mathrm{~b}$ & $5.4 \mathrm{~b}$ & $4.0 \mathrm{a}$ & $1.2 \mathrm{a}$ \\
\hline $1.5 \mathrm{mg} \mathrm{L}^{-1} \mathrm{BAP}+1.5 \mathrm{mg} \mathrm{L}^{-1} \mathrm{IAA}$ & $26.7 \mathrm{a}$ & $26.7 \mathrm{a}$ & $20.0 \mathrm{a}$ & $7.8 \mathrm{a}$ & $4.4 \mathrm{a}$ & $0.8 \mathrm{~b}$ \\
\hline
\end{tabular}

Means followed by the same letters in the column do not differ by the Duncan test $(p \leq 0.05)$. 


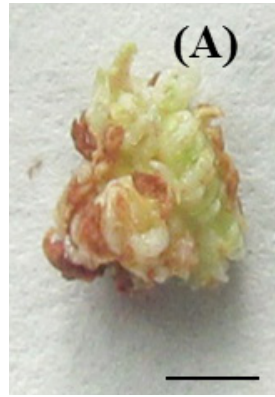

\section{(B)}

Figure 2: Adventitious bud formation in the morphogenic callus after three-four weeks of culture on the modified MS medium with $1.5 \mathrm{mg} \mathrm{L}^{-1} \mathrm{BAP}$ and $1.5 \mathrm{mg} \mathrm{L}^{-1} \mathrm{IAA}$ in the cultivars 'Iskorka Tavridy' (A, B) and 'Bergeron' (C) and on MS medium, supplemented with $1.3 \mathrm{mg} \mathrm{L}^{-1} \mathrm{TDZ}$ in the cultivar 'Magister' (D). Bar $=1 \mathrm{~cm}$.

Histological analysis of callus and morphogenic structures of the apricot cultivars 'Iskorka Tavridy', 'Bergeron' and 'Magister' demonstrated that gemmiferous callus and structures were represented by the globules of parenchyma cells at the periphery of which the areas of meristematically active cells were located. Meristematically active cells were in protodermal and subdermal layers of callus structures. The cells of protodermal layer mostly divided anticlinally. In subepidermal layers, cell divisions were both anticlinal and periclinal, increasing the volume of dividing cells pool. Thus, meristemoids, further produced adventitious buds and microshoots, were formed in meristematic zones (Figure 3).

During the meristem formation, procambium strands oriented on the microshoot apex were initiated in the mass of parenchyma cells and subsequently formed its vascular system. On the longitudinal sections of the advanced structures, the formation of several predominant meristems with developing leaves and meristems initiated in their axils were noted. In those structures vascular tissue strands were extended from the apical part to the basal one immersed in the culture medium. Thus, cytological differentiation in the studied apricot cultivars trended to indirect organogenesis and histogenesis.

Further studies of morphogenesis, adventitious bud and microshoot regeneration processes efficiency in vitro were carried at light intensity $37.5 \mu \mathrm{mol} \mathrm{m}^{-2} \mathrm{~s}^{-1}, 24 \pm 1^{\circ} \mathrm{C}$ and 16-hour photoperiod with subcultures on MS medium with plant growth regulators BAP, IAA or TDZ (Table 2).

In some literature sources various results regarding the influence of biotic and abiotic factors on the process of microshoot regeneration from the leaf explants of Prunus species under in vitro culture have been described (Burgos; Alburquerque, 2003; PerezTornero et al., 2000; Petri; Scorza, 2010; Ruiz et al., 2011).
These publications are mostly devoted to the problem of adventitious bud and microshoot regeneration from the plum leaves. As for the apricot, Perez-Tornero et al. (2000) noted that the percentage of adventitious shoots in vitro regenerated from leaves, was mostly dependent on the genotype and cytokinin used. The authors demonstrated that the regeneration capacity of 'Canino' cultivar was significantly higher (40-45\%) than that of 'Helena' cultivar (20-25\%), while the cultivars 'Bulida' and 'Lorna' had no regeneration or regeneration frequency was very low. The number of leaf explants that formed adventitious buds was significantly higher on the medium with TDZ. The best results were obtained using TDZ at the concentration of $1.9 \mathrm{mg} \mathrm{L}^{-1}$.

As a result of our research on the leaf explants morphogenetic capacity in three apricot cultivars, significant differences between the studied genotypes were shown. Thus, the presence of plant growth regulators BAP + IAA or TDZ in MS culture medium activated the process of the adventitious bud formation and microshoots regeneration in the studied cultivars. Data presented in the Table 2 demonstrate that, on MS culture medium with $1.5 \mathrm{mg} \mathrm{L}^{-1} \mathrm{BAP}+1.5 \mathrm{mg} \mathrm{L}^{-1} \mathrm{IAA}$, the number of adventitious buds formed per leaf explant in the cultivars 'Iskorka Tavridy" and 'Bergeron" was 8.2 and 3.6, respectively. The use of $1.3 \mathrm{mg} \mathrm{L}^{-1} \mathrm{TDZ}$, as cytokinin inducing shoot formation in difficult-topropagate plants, provided active regeneration in the cultivar 'Magister' (5.4 adventive buds per explant). The ability for further microshoot regeneration was also different and depended on the genotype (Figure 4). Thus, in the cultivar 'Iskorka Tavridy', the number of regenerated microshoots was up to $73.2 \%$, in the cultivar 'Magister' $-37.1 \%$, and in 'Bergeron' $-27.7 \%$ of the number of initiated adventitious buds. 


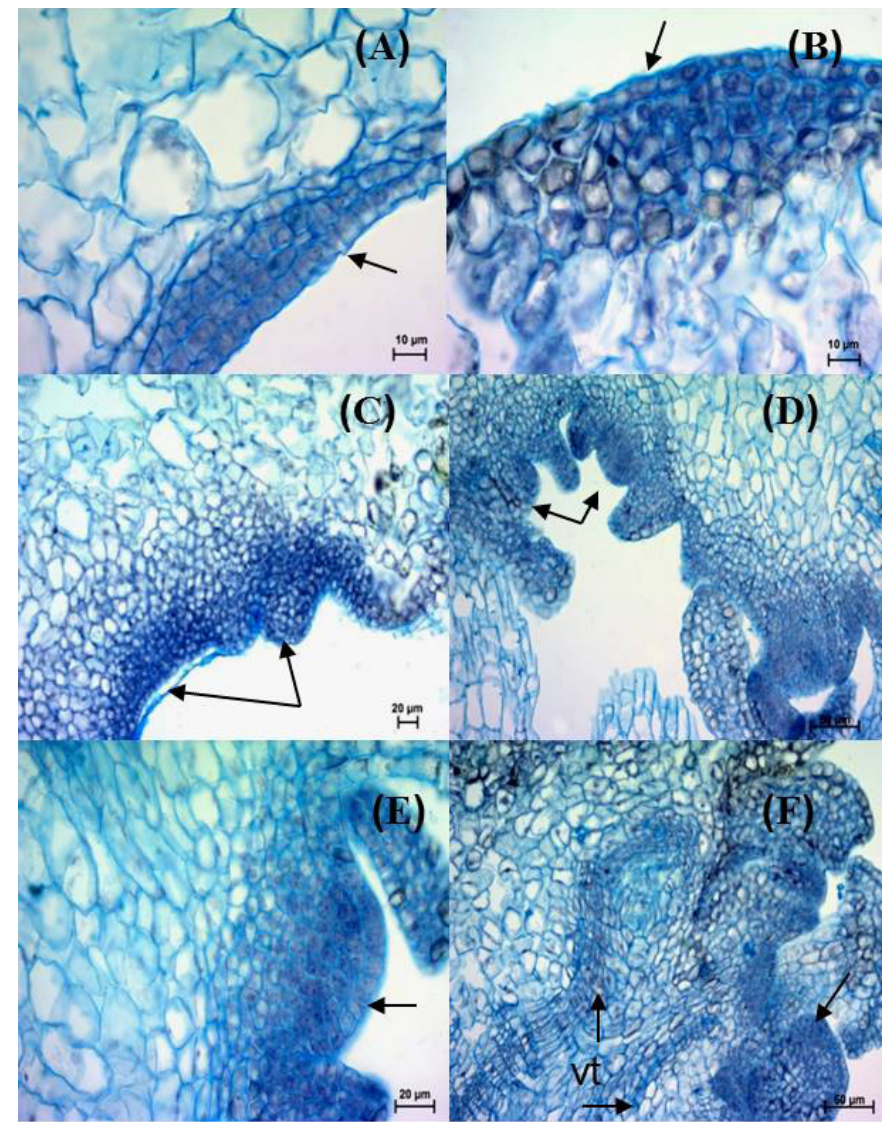

Figure 3: Stages of meristem formation (zones of meristematically active cells are indicated with arrows) at the periphery of callus in the apricot cultivar 'Iskorka Tavridy' (A, B), formation of the meristem domes and meristemoids (C, D), adventitious buds (E) and longitudinal section of the adventive microshoot with the elements of vascular system (vt) (F).

Table 2: Adventitious bud regeneration efficiency in three apricot cultivars on MS culture medium.

\begin{tabular}{ccc}
\hline \multirow{2}{*}{ Cultivar } & Plant growth regulator and concentration & Number of adventitious buds / explant \\
\cline { 2 - 3 } 'Iskorka Tavridy' & 0 (control) & $0.0 \mathrm{~d}$ \\
& $0.6 \mathrm{mg} \mathrm{L}^{-1} \mathrm{TDZ}$ & $3.8 \mathrm{bc}$ \\
& $1.3 \mathrm{mg} \mathrm{L}^{-1} \mathrm{TDZ}$ & $5.2 \mathrm{ab}$ \\
& $1.5 \mathrm{mg} \mathrm{L}^{-1} \mathrm{BAP}+1.5 \mathrm{mg} \mathrm{L}^{-1} \mathrm{IAA}$ & $8.2 \mathrm{a}$ \\
\hline \multirow{3}{*}{ 'Magister' } & 0 (control) & $0.0 \mathrm{~d}$ \\
& $0.6 \mathrm{mg} \mathrm{L}^{-1} \mathrm{TDZ}$ & $1.8 \mathrm{c}$ \\
& $1.3 \mathrm{mg} \mathrm{L}^{-1} \mathrm{TDZ}$ & $5.4 \mathrm{a}$ \\
& $1.5 \mathrm{mg} \mathrm{L}^{-1} \mathrm{BAP}+1.5 \mathrm{mg} \mathrm{L}^{-1} \mathrm{IAA}$ & $4.2 \mathrm{ab}$ \\
\hline & $0($ control) & $0.0 \mathrm{~d}$ \\
'Bergeron' & $0.6 \mathrm{mg} \mathrm{L}^{-1} \mathrm{TDZ}$ & $2.2 \mathrm{c}$ \\
& $1.3 \mathrm{mg} \mathrm{L}^{-1} \mathrm{TDZ}$ & $2.8 \mathrm{ab}$ \\
& $1.5 \mathrm{mg} \mathrm{L}^{-1} \mathrm{BAP}+1.5 \mathrm{mg} \mathrm{L} \mathrm{L}^{-1} \mathrm{IAA}$ & $3.6 \mathrm{a}$ \\
\hline
\end{tabular}

Means followed by the same letters in the column do not differ by the Duncan test $(p \leq 0.05)$. 

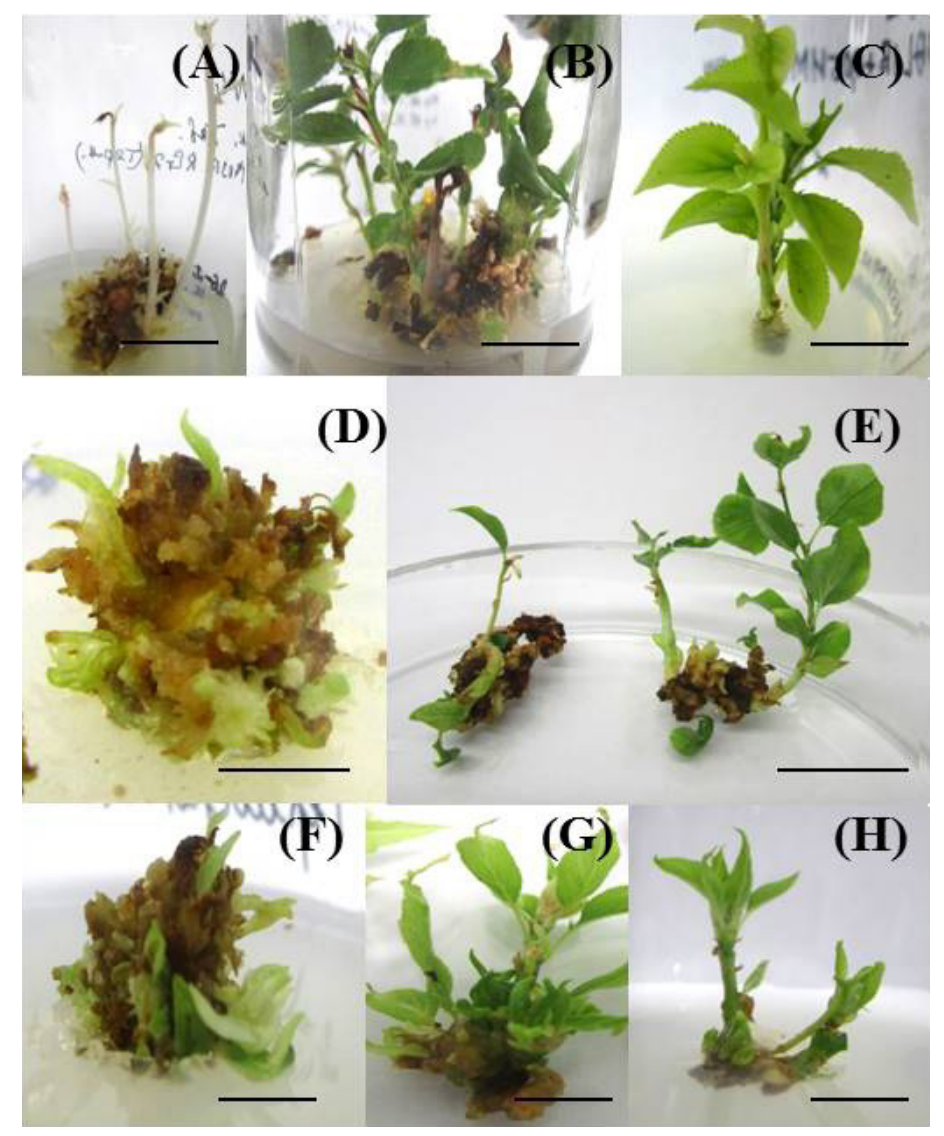

Figure 4: Indirect regeneration of adventitious microshoots in the morphogenic callus of three apricot cultivars 'Iskorka Tavridy' (A-C), 'Magister' (D, E) and 'Bergeron' (F-H). Microshoot formation in the cultivar 'Iskorka Tavridy' on MS medium supplemented with $1.5 \mathrm{mg} \mathrm{L}^{-1} \mathrm{BAP}$ and $1.5 \mathrm{mg} \mathrm{L}^{-1} \mathrm{IAA}$ after four (A), four-five (B) and five-six (C) weeks in culture. Adventitious bud formation and the beginning of microshoots development in the cultivar 'Magister' on MS medium with $1.3 \mathrm{mg} \mathrm{L}^{-1} \mathrm{TDZ}$ after 3-4 weeks cultivation (D), microshoot obtaining after four-five weeks in culture (E). Morphogenic structures formation (F) after three-four weeks and microshoots regeneration $(G, H)$ after four-five weeks cultivation in the cultivar 'Bergeron' on MS medium with $1.5 \mathrm{mg} \mathrm{L}^{-1} \mathrm{BAP}$ and $1.5 \mathrm{mg} \mathrm{L}^{-1} \mathrm{IAA} . \mathrm{Bar}=1 \mathrm{~cm}$.

At leaf callus subculture on regeneration medium for six-eight months adventitious bud and microshoot formation was continued. Increasing of the microshoots number during four-six months was depended on genotype and then the regeneration capacity gradually decreased (Figure 5).

The cultivar 'Iskorka Tavridy' had a higher morphogenetic capacity. The maximum number of adventitious microshoots was obtained after five and six months culture (17.7 and 18.2 microshoots per explant, respectively).

The number of microshoots obtained from the leaf callus in the cultivar 'Magister' did not exceed five ones under the sixth subculture. A low regeneration rate of microshoots per explant was obtained in the cultivar 'Bergeron'. As the morphogenetic capacity decreased, the callus surface darkened (became brown), but regeneration continued until viable green zones were presented in the callus.

Adventitious microshoots of the cultivars 'Iskorka Tavridy', 'Magister' and 'Bergeron' were tested for their ability to rhizogenesis. Microshoots 2.0-3.5 cm long with six-seven leaves were placed on the rooting medium $(1 / 2$ MS) supplemented with 1.0, 2.0 and $3.0 \mathrm{mg} \mathrm{L}^{-1}$ IBA for root formation (Figure 6). During the culture on halfstrength MS medium with $3.0 \mathrm{mg} \mathrm{L}^{-1}$ IBA thickened roots were obtained.

The roots appeared after three-four weeks culture and after five-six weeks were up to $1.5-2 \mathrm{~cm}$ long. The best root formation was observed on the medium supplemented with $2.0 \mathrm{mg} \mathrm{L}^{-1} \mathrm{IBA}$. Regenerated plantlets were transferred to acclimatization ex vitro (Figure 7). 


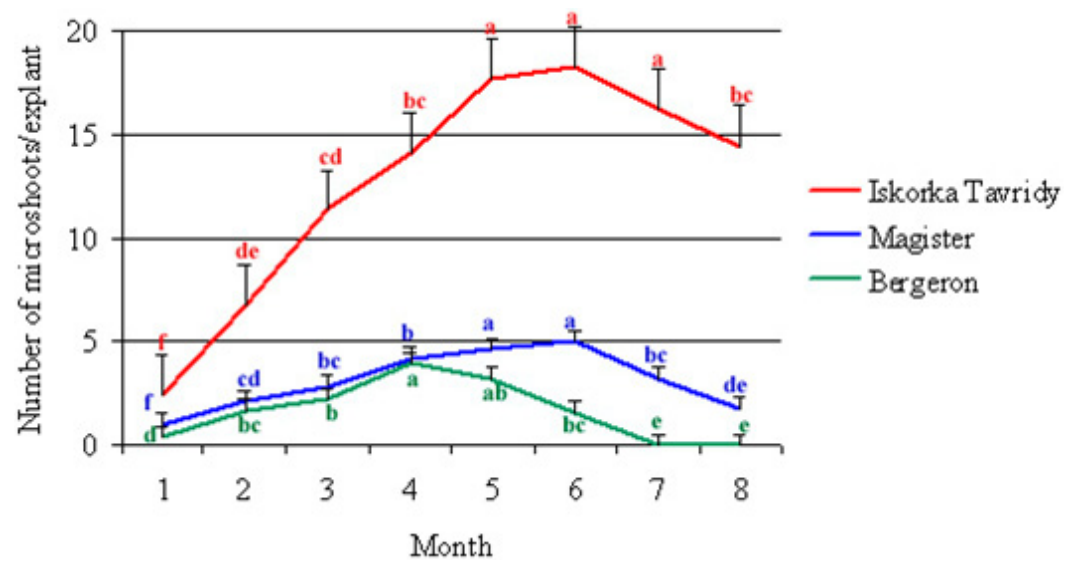

Figure 5: Microshoot regeneration in three apricot genotypes depending on culture duration: 'Iskorka Tavridy', 'Bergeron' on MS medium, supplemented with $1.5 \mathrm{mg} \mathrm{L}^{-1} \mathrm{BAP}$ and $1.5 \mathrm{mg} \mathrm{L}^{-1} \mathrm{IAA}$, and cultivar 'Magister' on MS medium with $1.3 \mathrm{mg} \mathrm{L}^{-1} \mathrm{TDZ}$.

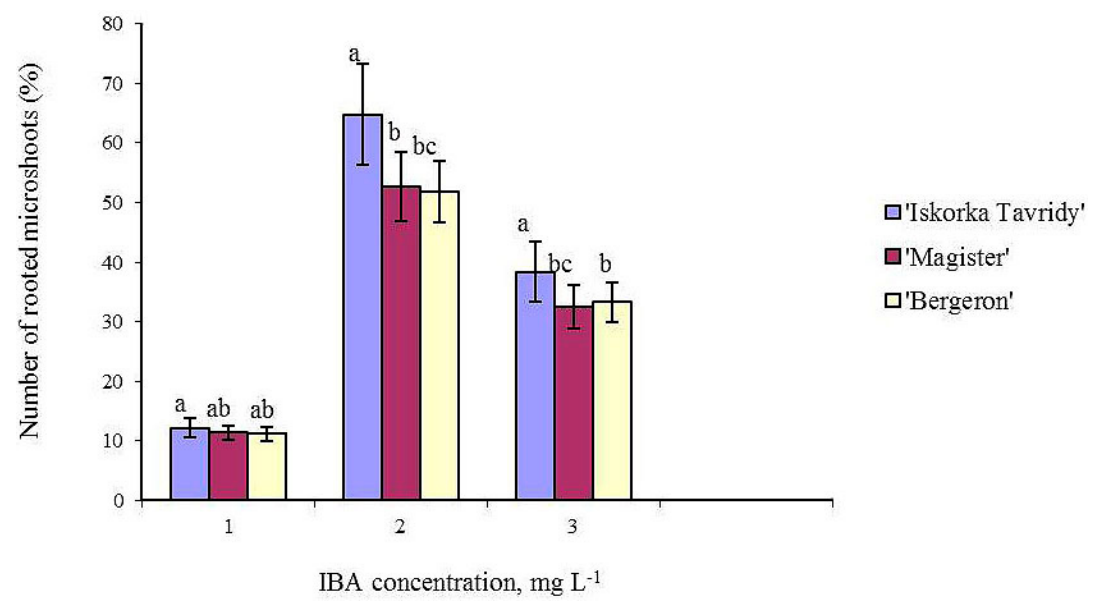

Figure 6: Apricot microshoot rhizogenesis on $1 / 2 \mathrm{MS}$ medium with different IBA concentrations.

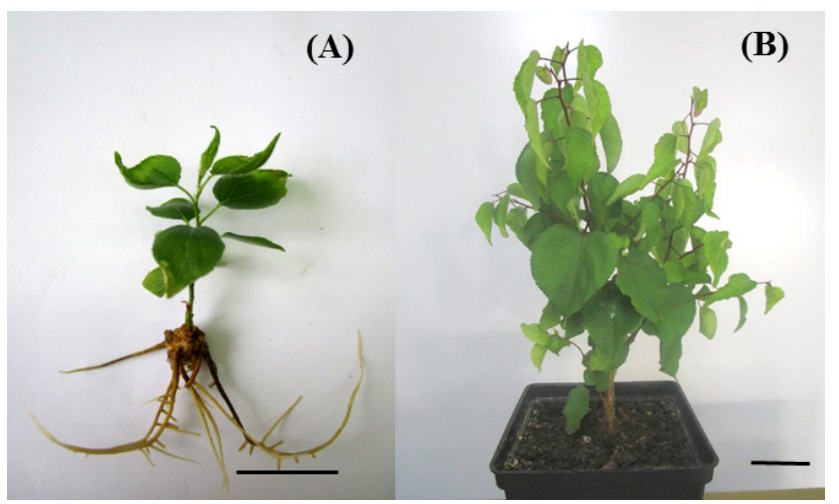

Figure 7: Plantlets of the apricot cultivar 'Iskorka Tavridy' regenerated from leaf morphogenic callus before their adaptation ex vitro (A) after five-six weeks of culture in vitro. Bar $=1 \mathrm{~cm}$. The plant of the apricot cultivar 'Iskorka Tavridy' after six month of adapted in vivo (B). Bar $=5 \mathrm{~cm}$. 


\section{CONCLUSIONS}

The system of indirect regeneration from leaf explants for three apricot cultivars ('Iskorka Tavridy', 'Magister' and 'Bergeron') has been developed. For the first time, possibilities of leaf explant morphogenetic capacity has been studied in the apricot cultivars 'Iskorka Tavridy' and 'Magister'. It has been demonstrated that adventitious bud and microshoot formation occurred via indirect organogenesis on MS, QL and WPM media supplemented with $1.5 \mathrm{mg} \mathrm{L}^{-1} \mathrm{BAP}$ and $1.5 \mathrm{mg} \mathrm{L}^{-1} \mathrm{IAA} ; 0.6$ and $1.3 \mathrm{mg}$ $\mathrm{L}^{-1} \mathrm{TDZ}$. At the same time, regeneration frequency on MS medium with BAP and IAA in concentrations of $1.5 \mathrm{mg} \mathrm{L}^{-1}$ reached $80.0 \%, 53.3 \%$ and $50.0 \%$ in the cultivars 'Iskorka Tavridy', 'Magister' and 'Bergeron', respectively. The results of histological analysis confirmed meristemoid and adventitious bud formation inside and on the surface of the morphogenic callus. Roots $1.5-2.0 \mathrm{~cm}$ long were formed on the medium supplemented with $2.0 \mathrm{mg} \mathrm{L}^{-1} \mathrm{IBA}$ and plantlets of apricot were obtained.

\section{ACKNOWLEDGMENTS}

This study was funded by a research grant № 1450-00079 of the Russian Science Foundation.

\section{REFERENCES}

BURGOS, L.; ALBURQUERQUE, N. Low kanamycin concentration and ethylene inhibitors improve adventitious regeneration from apricot leaves. Plant Cell Reports, 21:1167-1174, 2003.

BOURGUIBA, $\mathrm{H}$. et al. Genetic structure of a worldwide germplasm collection of Prunus armeniaca L. Acta Horticulturae, 1214:203-206, 2018.

CAMBRA, M. et al. Plum pox virus and the estimated costs associated with sharka disease. Bulletin OEPP/EPPO Bulletin, 36:202-204, 2006.

ESCALETTES, V.; DOSBA, F. In vitro adventitious shoot regeneration from leaves of Prunus spp. Plant Science, 90(2):201-209, 1993.

GENTILE, A.; MONTICELLI, S.; DAMIANO, C. Adventitious regeneration in peach [Prunus persica (L.) Batsch]. Plant Cell Reports, 20:1011-1016, 2002.

GORINA, V.; RICHTER, A. Specific features of the inheritance of some traits in apricot. Acta Horticulturae, 1208:183-190, 2018.

ILARDI, V.; TAVAZZA, M. Biotechnological strategies and tools for Plum pox virus resistance: Trans-, intra-, cis-genesis, and beyond. Frontiers in Plant Science, 6:379, 2015.
KORZIN, V. V.; GORINA, V. M.; MESYATS N. V. Evaluation of new breeding forms of apricot in the Nikitsky Botanical Gardens. Bulletin of the State Nikita Botanical Gardens, 126:82-86, 2018.

KRAMARENKO, L. A. Introduction of apricot to Moscow and surrounding regions: Results of 32 years of work. Acta Horticulturae, 1214:45-52, 2018.

KYTE, L. et al. Plants from test tubes: An introduction of micropropagation. Portland, Oregon: Timber Press, 2013. 273p.

LLOYD, G.; MCCOWN, B. Commercially-feasible micropropagation of mountain laurel, Kalmia latifolia, by use of shoottip culture. Proceedings of the International Plant Propagator's Society, 30:420-427, 1980.

MITROFANOVA, I. V. Somatic embryogenesis and organogenesis as the basis of biotechnology for obtaining and preservation of perennial garden crops. Kyiv: Agrarna Nauka, 2011. 344p.

MITROFANOVA, I. et al. Detection and Identification of Plum Pox Virus on Prunus species in Crimea. Journal Agriculture \& Forestry, 61(4):197-204, 2015.

MITROFANOVA, I. V. et al. Three highly divergent groups of Plum pox virus strain $D$ isolates coexist in stone-fruit plantings of Nikita Botanical Gardens, Crimea. Acta Horticulturae, 1163:117-122, 2017.

MITROFANOVA, O. V. et al. Biotechnological methods in subtropical and stone fruit crops breeding and reproduction. Works of the State Nikita Botanical Gardens, 118:189199, 1999.

MITROFANOVA, O. V. et al. Peculiarities of the microshoot regeneration in some peach cultivars under in vitro conditions. Bulletin of the State Nikita Botanical Gardens, 121:48-56, 2016.

MOURENETS, L. Y.; DOLGOV, S. V. Adventitious shoot regeneration from leaf explants of two apricot rootstocks. Acta Horticulturae, 1139:285-290, 2016.

MURASHIGE, T.; SKOOG, F. A revised medium for rapid growth and bioassays with tobacco tissue cultures. Physiologia Plantarum, 15:473-497, 1962.

NEMETH, M. History and importance of Plum pox virus in stone-fruit production. Bulletin OEPP/EPPO Bulletin of the European and Mediterranean Plant Protection Organization, 24:525-536, 1994. 
NOZDRACHEVA, R. G. Apricot in the Central Chernozem

Region. Voronezh: Federal State Educational Institution of Higher Professional Education of the Volga State University, 2008. 239p.

PEREZ-TORNERO, O.; BURGOS, L. Apricot micropropagation. In: JAIN, S. M.; HAGGMAN, H. (Eds.). Protocols for Micropropagation of Woody Trees and Fruits. Dordrecht: Springer, 2007. p.267-278.

PEREZ-TORNERO, O.; BURGOS, L.; EGEA, J. Introduction and establishment of apricot in vitro through regeneration of shoots from meristem tips. In Vitro Cellular \& Developmental Biology-Plant, 35:249-253, 1999.

PEREZ-TORNERO, O. et al. Assessment of factors affecting adventitious shoot regeneration from in vitro cultured leaves of apricot. Plant Science, 158:61-70, 2000.

PETRI, C.; ALBURQUERQUE, N.; BURGOS, L. Apricot (Prunus armeniaca L.) In: WANG, K. (Ed.) Methods in Molecular Biology: Agrobacterium Protocols. New York: Springer Science+Business Media, 2015. v.2, p.111-119.

PETRI, C.; SCORZA, R. Factors affecting adventitious regeneration from in vitro leaf explants of 'Improved French' plum, the most important dried plum cultivar in the USA. Annals of Applied Biology, 156:79-89, 2010.

POTTER, D. Basic information on the stone fruit crops. In: KOLE, C.; ABBOT, A. G. (Eds.) Genetics, Genomics and Breeding of Stone Fruits. CRC Press Taylor\&Francis Group, 2012. p.1-21.

QUOIRIN, M.; LEPOIVRE, P. Improved medium for in vitro culture of Prunus spp. Acta Horticulturae, 78:437-442, 1977.

RUBIO, M. et al. Multi-resistance of apricot cultivars to the most important diseases in Spain. Acta Horticulturae, 1214: 231-234, 2018.

RUIZ, D. et al. Application of biotechnology tools to apricot breeding. Fruit, Vegetable and Cereal Science and Biotechnology, 5(1):101-117, 2011.

ZHEBENTYAYEVA, T. et al. Apricot. In: BADENES, M. L.; BYRNE, D. H. (Eds.) Fruit Breeding. Handbook of Plant Breeding 8. New York: Springer Science+Business Media, 2012. p.415-458.

ZHINKINA, N. A.; VORONOVA, O. N. About the technique of embryological sections staining. Botanicheskij Zhurnal, 85(6):168-171, 2000. 